\title{
Middlesex University
}

Business School London

Middlesex

University

\section{LLM Opportunities at Middlesex University Business School Centre for Legal Research, London - LLM Programme}

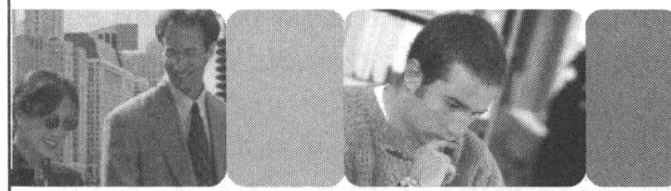

This is a flexible, student-centred, and distinctive LLM programme designed to cater for both UK/EU and international students. The primary aim of this programme is to provide students who wish to develop their interests in specialised areas of law and enhance their marketability with a quality legal education in a vibrant, interdisciplinary and cosmopolitan environment.

Students can either opt for an assortment of courses available to obtain the general LLM or follow a designated pathway to be eligible for either an LLM in International Economic Law or an LLM in International Business Law. Courses on offer at present include, International Law of Trade, International Commercial Transactions, International Economic Law, Competition Law, International Commercial

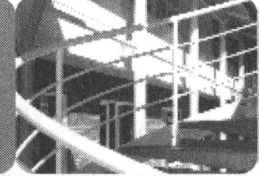

Arbitration, Human Rights Law, Environmental Law and various Employment Law related subjects. There is a strong research element incorporated into the programme.

The Programme Leader is Professor Surya P Subedi who is Director of the Centre for Legal Research within the University. He has taught international law in The Hague, New York and Sweden.

The Centre also offers the following programmes:

LLM Employment Law • MA Legal Studies PG Diploma in Law/CPE

- plus opportunities for research in International Economic Law, International Business Law and Employment Law, leading to an MPhil or a PhD degree in Law.

Admissions Enquiries, Middlesex University, North London Business Park, London N11 1QS, UK +44(0)20 84115898 • http://mubs.mdx.ac.uk • admissions@mdx.ac.uk

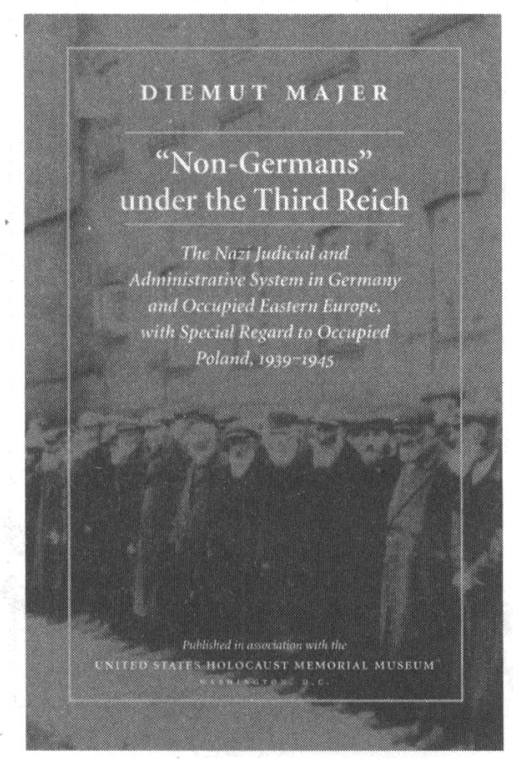

1,088 pages

\section{"Non-Germans" under the Third Reich}

The Nazi Judicial and Administrative System in Germany and Occupied Eastern Europe, with Special Regard to Occupied Poland, 1939-1945

Diemut Majer

translated by Peter Thomas Hill, Edward Vance Humphrey, and Brian Levin

"An exhaustive analysis of the numerous legal and executive provisions and practices applicable to 'Fremdvölkische.' I consider it the only scholarly work of this nature that addresses all of the people concerned and the treatment they received from the Nazi authorities."-Walter O. Weyrauch, University of Florida

"There has not been such a comprehensive presentation of the Third Reich's legal system before, and it will be a long time before another-written by a single author-appears." -Juristen-Zeitung, reviewing the German edition

Published in association with the United States Holocaust Memorial Museum

The Johns Hopkins University Press • 1-800-537-5487 • www. press.jhu.edu 


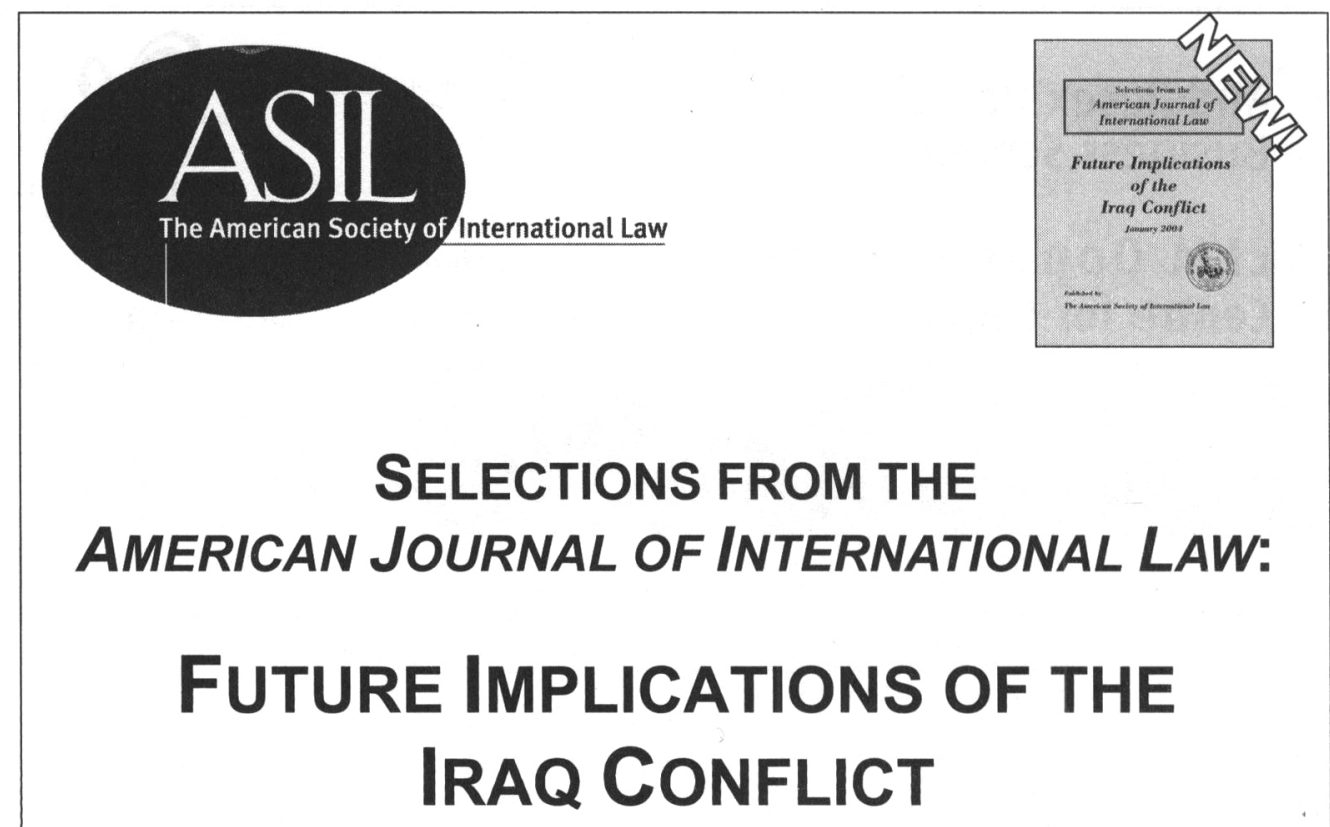

Will military action in Iraq in spring 2003 lead to fundamental transformation or possible destruction of the UN Charter system of law on the use of force? This inaugural Selections contains more than a dozen essays on the Iraq conflict-all with an eye to the future-written by a distinguished group of scholars and attorneys, including Eyal Benvenisti, Todd F. Buchwald, Richard A. Falk, Tom J. Farer, Thomas M. Franck, Richard N. Gardner, Thomas D. Grant, Miriam Sapiro, David J. Scheffer, Carsten Stahn, Jane E. Stromseth, Ruth Wedgwood, John Yoo, and the Legal Adviser of the U.S. Department of State, William H. Taft IV. Originally appearing in an Agora in the July and October 2003 issues of the American Journal of International Law, these contributions are supplemented by the six relevant UN resolutions and other materials, making Selections an excellent classroom tool.

\section{Order Future Implications of the Iraq Conflict today for only $\$ 20$ !}

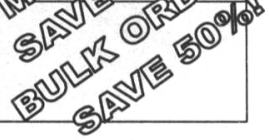

To learn more about and order Future Implications of the Iraq Conflict, visit the ASIL Web site <wWw.asil.org>.

The American Society of International Law, P.O. Box 501193, St. Louis, MO 63150-1193 USA, (p) 781-876-8844 (f) 202-986-4234, (u) www.asil.org 


\title{
JOURNAL OF THE HISTORY OF INTERNATIONAL LAW
}

\author{
Announcement \\ and \\ Call for Manuscripts
}

The Journal of the History of International Law is under new editorship with effect from Volume 6 (2004).

The new Editors-in-Chief are:

Peter Haggenmacher, Professor of Public International Law, Graduate Institute of International Studies, Geneva.

Michael Stolleis, Professor of Public Law, Director, Max Planck Institute for European Legal History, Frankfurt/Main.

Rüdiger Wolfrum, Professor of Public International Law, Director, Max Planck Institute for Comparative Public Law and International Law, Heidelberg.

The Journal appears biannually. The languages of the contributions are English and French.

The aim of the Journal is to contribute to make intelligible the international legal past, and to promote the application of a sense of historical proportion to current international legal problems.

The Journal will seek to open new fields of enquiry, and will encourage different methods of approaching the history of international law.

The editors are interested in receiving manuscripts for consideration for publication in the forthcoming issues. Essays should if possible be limited to about 20 pages. Scholarly research papers should be no more than 35 pages. Books for review and further suggestions will be welcome.

Correspondence and Manuscripts may be addressed to one of the editors, or to

Journal of the History of International Law

Max Planck Institute for Comparative Public Law

and International Law

Im Neuenheimer Feld 535

D-69120 Heidelberg

e-mail: jhil@mpil.de 


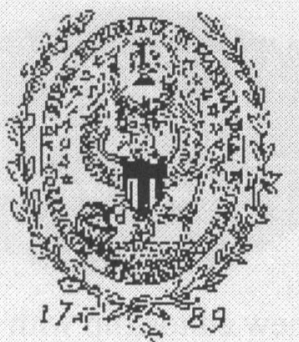

\section{ANNOUNCING THE \\ GEORGETOWN JOURNAL \\ OF \\ INTERNATIONAL LAW}

The Georgetown Journal of International Law (GJIL), formerly known as Law and Policy in International Business ( $L P I B)$, is the general international law journal of the Georgetown University Law Center. Reflecting the Law Center's expertise and reputation as a premier institution for the study of international law, GJIL will continue LPIB's tradition of publishing quality scholarship as it expands its scope to include general international law issues as well as international business.

GJIL publishes four issues annually and is now accepting submissions for upcoming issues. To submit a manuscript, contact:

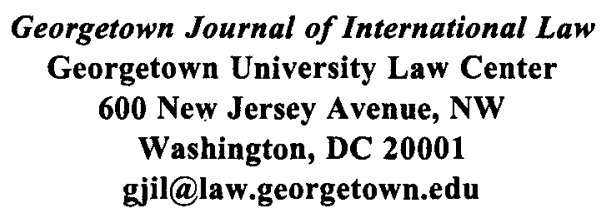

A one-year subscription to GJIL is $\mathbf{\$ 3 5 . 0 0}$. Single issues are available for $\mathbf{\$ 1 2 . 5 0}$. To subscribe to GJIL, please photocopy this page and complete the bottom portion. Return it with your check or money order to:

\section{Georgetown University Law Center \\ Office of Journal Administration \\ Attention: Subscriptions \\ 600 New Jersey Avenue, NW \\ Washington, DC 20001}

I would like to subscribe to the Georgetown Journal of International Law. Below is my personal information including the address to which my issues will be sent:

Name (first, last):

Firm:

Address:

City, State: Zip Code:

Phone number:

Email: 


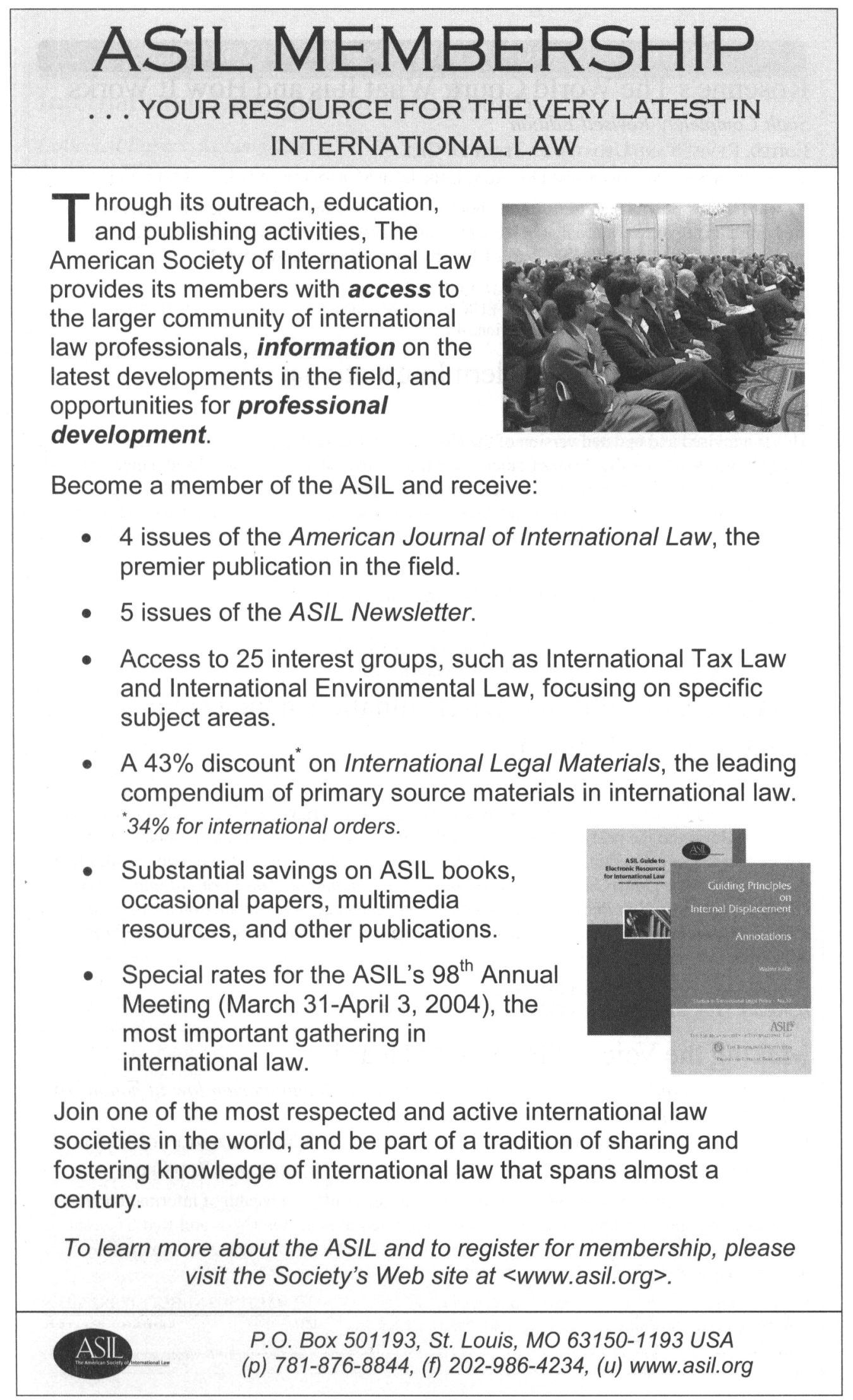


As was true for previous editions of this book, the present edition offers the non-specialist reader: the politician, diplomat, journalist or student of international law and relations - a guide and introduction to the International Court of Justice; what it is and how it works.

In print $2004 \quad$ ISBN 9004136339

Hardback (xx, 332 pp.) List price EUR 80.- / US\$ 100.-

Legal Aspects of International Organization, 40

\section{The Perplexities of Modern International Law}

ShabTai Rosenne

This is a revised and updated version of the General Course on Public International Law.

Every 'precedent', whether legal or other, must first be placed in its historical and temporal context before we can see if it is applicable in new circumstances and the historical evolution of any notion or concept is important for an understanding of its current implications. Through a close linkage between law and history, the author takes us through the evolution of international law to where it stands today.

Co-publication with The Hague Academy of International Law

March $2004 \quad$ ISBN 9004136924

Hardback (xxvi, 472 pp.) List price EUR 108.- / US\$ 135.-

The Hague Academy of International Law Monographs, 2

\section{Challenge of Religious Discrimination at the Dawn of the New Millennium}

Edited by Nazila Ghanea

The themes and issues explored in this book - religion, human rights, politics and society could not be more relevant to the post 11 September 2001 world. They lie at the heart of global political debate today. The collection explores these issues after the passing of just over two decades from the adoption of the United Nations Declaration on the Elimination of all Forms of Intolerance and Discrimination based on Religion or Belief. Sadly the challenge of intolerance on the basis of religion or belief continues to plague us, and tackling it seems to have become increasingly entrenched.

In print 2004

ISBN $900413641 \mathrm{X}$

Hardback (viii, 270 pp.) List price EUR 75.- / US\$ 94.-

\section{Making the Voice of Humanity Heard}

Essays on humanitarian assistance and international humanitarian law in honour of HRH Princess Margriet of the Netherlands

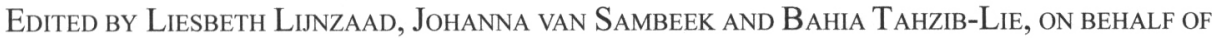
the Netherlands Ministry of Foreign Affairs and the Netherlands Red Cross

This unique collection of scholarly and inspirational essays offers a wealth of information on the constituent components and statutory bodies of the International Red Cross and Red Crescent Movement and contemplates its mission to help victims and improve the lives of vulnerable people. 


\section{NEW TITLES FROM MARTINUS NIJHOFF PUBLISHERS}

\section{International Law and Political Reality}

Collected Papers: Volume One

AnTHONy D'Amato

Among the topics that D'Amato examines in these studies of the interrelationship between international law and political reality are wars and war crimes, nuclear weapons and technology, sanctions and terrorism, covert and humanitarian intervention, and group and autonomy rights.

In print 1995

ISBN 9041100369

Hardback (404 pp.)

List price EUR 119.- / US\$ 161.-

\section{International Law Studies}

Collected Papers: Volume Two

ANTHONY D'AMATO

In this second volume of collected papers, the author addresses: - environmental law, - human rights, - international criminal law, - foreign relations law, - the intersection of political science and international law, and - the study and practice of international law. The insightful and probing nature of the author's wholly new analysis of these critical topics will intrigue any international law scholar or practitioner.
In print 1997
ISBN 9041103805
Hardback (404 pp.)
List price EUR 113.- / US\$ 153.-

\section{International Law Sources}

Collected Papers: Volume Three

Anthony D'Amato

Martinus Nijhoff Publishers is pleased to announce the third volume of this acclaimed series. In this volume, the author updates his essays on sources and the foundational questions of international law with new commentary.

'My sketch of Grotius fits D'Amato better than any other Englishwriting international legal scholar today. It is the cumulative effect of D'Amato's great body of work that warrants attention, now and far into the future.'

Nicholas Onuf.

'The main impression imparted by the volume as a whole is one of jurisprudential coherence and striking originality. It establishes Anthony D'Amato as one of the finest theoretical minds at work on international law issues, and it does so in an engaging manner that gives a reader the pleasure of participating actively in these explorations into the nature and function of international law.' Richard A. Falk.

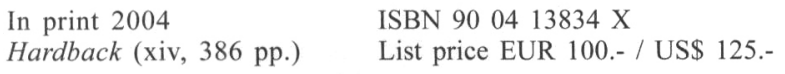

\section{MARTINUS NIJHOFF PUBLISHERS}

visit us at LEIDEN - BOSTON an imprint of Brill Academic Publishers www.brill.nl

\begin{tabular}{|c|c|c|c|}
\hline Extenza-Turpin & & For North America & Tel 1-800-337-9255 \\
\hline Stratton Business Park & Tel +44 (0)1767 604954 & Brill Academic Publishers & (toll free, USA \& Canada only) \\
\hline Pegasus drive, Biggleswade & $\mathrm{Fax}+44(0) 1767601640$ & P.O. Box 605 & $1-703-661-1585$ \\
\hline Bedfordshire SG18 8QB & E-mail: & Herndon, VA 20172 & Fax 1-703-661-1501 \\
\hline United Kingdom & brill@extenza-turpin.com & USA & E-mail cs@brillusa.com \\
\hline
\end{tabular}




\section{COMING FALL 2004}

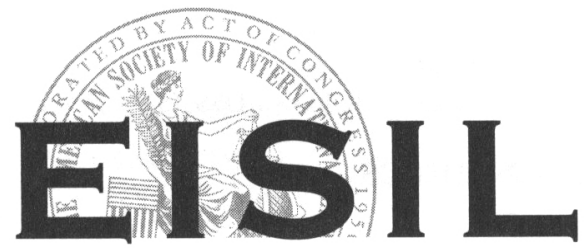

THE ELECTRONIC INFORMATION SYSTEM FOR INTERNATIONAL LAW

BROUGHT TO YOU BY

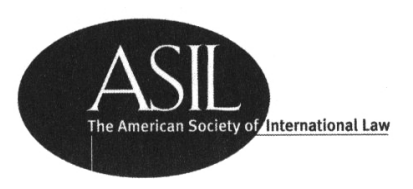




\section{CAMBRIDGE}

\section{Outstanding Scholarship from Cambridge}

Private Power and Global Authority

Transnational Merchant Law in the Global Political Economy

A. Claire Cutler

Cambridge Studies in International Relations 90

\$65.00: Hardback: 0-521-82660-8: 326pp

\$24.00: Paperback: 0-521-53397-X

The Internationalisation of Antitrust Policy

Maher M. Dabbah

\$70.00: Hardback: 0-521-82079-0: 346pp

Restitutionary Rights to Share in Damages

Carers' Claims

Simone Degeling

\$70.00: Hardback: 0-521-80065-X: 312pp

European Conquest and the Rights of Indigenous Peoples The Moral Backwardness of International Society

Paul Keal

Cambridge Studies in International Relations 92

\$70.00: 0-521-82471-0: Hardback: 274pp

\$25.00: 0-521-53179-9: Paperback

The Rational Design of International Institutions

Edited by Barbara Koremenos, Charles Lipson, and Duncan J. Snidal

International Organization

\$30.00: 0-521-53358-9: Paperback: 365pp

The Relationship between European Community Law and National Law

Volume 2: The Cases

Edited by Andrew Oppenheimer

\$180.00: Hardback: 0-521-63098-3: 732pp

The Practice and Procedure of the Inter-American Court of Human Rights

Jo M. Pasqualucci

\$140.00: Hardback: 0-521-82595-4: 536pp

\$50.00: Paperback: 0-521-53335-X
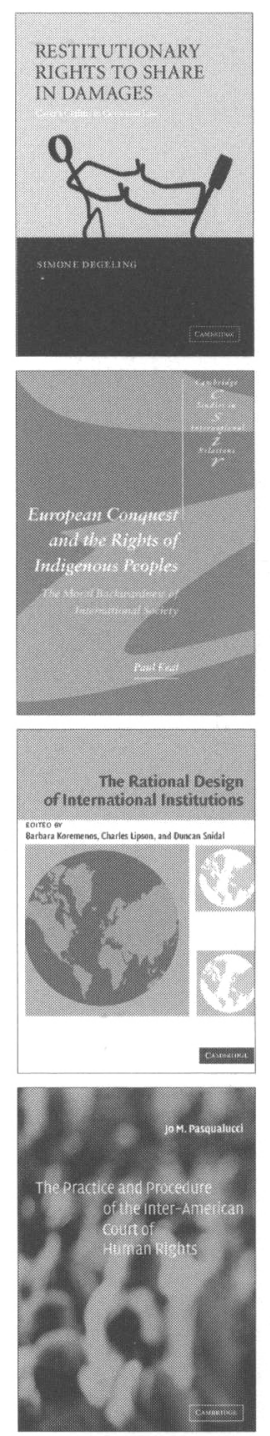

\section{IMPORTANT NOTICE:}

Cambridge University Press is delighted to announce that, as of January 1, 2004, it will become the exclusive distributor of the English-language books and journals of the T.M.C. Asser Press. The T.M.C. Asser Press is the publishing house of the T.M.C. Asser Institute in The Hague, and the collaboration between Cambridge and Asser marks another major step in the growth and expansion of law publishing at Cambridge. The T.M.C. Asser Press publishes work aimed at both scholars and professionals in the fields of the Institute, private and public international law, European law, international criminal and humanitarian law, international commercial arbitration and international sports law. 


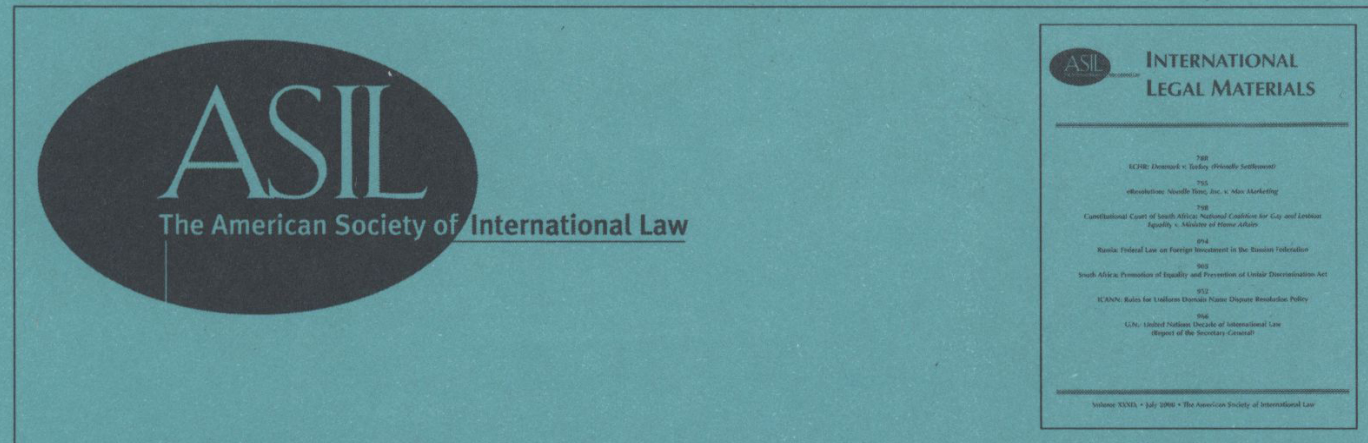

\section{PROBLEM SOLVED.}

Subscribe to International Legal Materials, and solve a few modern problems:

$>$ Web sites come and go, taking the usefulness of your citations with them.

$>$ Most libraries are not repositories of U.N. Treaties and arbitral decisions.

$>$ You cannot write notes in the margins on your computer screen.

$>$ Information is not at your fingertips when Internet searches yield 2,349 results.

Visit the ASIL Web site <www.asil.org>, sign up for $I L M$, and relax.

...problem solved. 